\title{
FREE VIBRATIONS OF COLUMN LOCALLY RESTING ON THE WINKLER ELASTIC FOUNDATION UNDER THE SPECIFIC LOAD
}

\author{
Janusz Szmidla, Ilona Cieślińska-Gąsior \\ Institute of Mechanics and Machine Design Foundation, Czestochowa University of Technology \\ Czesstochowa, Poland \\ szmidla@imipkm.pcz.czest.pl, cieslinskailona@wp.pl
}

\begin{abstract}
The results of theoretical and numerical research into free vibrations of column subjected to the follower force directed towards the positive pole locally resting on Winkler elastic foundation were presented in this work. Differential equations of motion and boundary conditions of considered system were determined taking into account total mechanical energy and Hamilton's principle. On the basis of solution of boundary problem, the courses of free vibrations frequency curves as a function of external load were obtained taking into consideration parameters of length and location of Winkler elastic base and also parameters describing loading head geometry.
\end{abstract}

Keywords: critical load, Winkler elastic foundation, free vibrations

\section{Introduction}

Slender systems have been discussed in a lot of scientific studies where issues of stability for various cases of fixing and loading were analysed. Different cases of conservative Euler's load [1], specific load [2] and nonconservative load (generalised Beck's load) [3] were taken into account.

The work [4] examined a slender system subjected to the follower force directed towards the positive pole - a case of specific load that was described for the first time by Tomski [5]. The column built of loading and receiving heads with circular outlines (constant curvature) was considered in publication [6]. The boundary conditions were defined on the basis of total mechanical energy of analysed system.

The issue of vibrations of column resting on elastic base is of real practical significance. This problem was investigated by many authors $[7,8]$. The simplest model of weightless continuous Winkler elastic foundation was adopted in this work. Abovementioned model is allowed for soft and lightweight foundations [9]. The geometrically nonlinear column with internal rod supported by Winkler elastic 
base along the entire length (partially) was described in [7]. Total mechanical energy, differential equations of motion and boundary conditions were determined in this publication. The conducted numerical simulations concerned changes in courses of free transverse vibration frequency as a function of selected geometrical and physical parameters of loading heads.

The problem discussed in this paper is close to the issues of local instability of slender shell resting on an elastic foundation [10]. It is also worth noting that the problems of instability very frequently are characterized by high sensitivity due to the parameters of the considered system [11].

\section{The physical model}

The loading by follower force directed towards the positive pole (Fig. 1) is realized by loading and receiving heads with circular outlines (constant curvature). The system is loaded by external force $P$ which direction passes through stationary point $O$. The direction of force is also tangential to the line of deflection at the free end of system $(x=L)$. The total length of $\mathbf{K L}$ column is marked as $L$ and equals:

$$
L=l_{1}+l_{2}+l_{3}
$$

In order to model the local support by elastic base with stiffness coefficient $K$, the system was divided into three rods with flexural rigidity $(E J)_{1},(E J)_{2},(E J)_{3}$, compression rigidity $(E A)_{1},(E A)_{2},(E A)_{3}$ and mass per unit length $(\rho A)_{1},(\rho A)_{2}$, $(\rho A)_{3}$ respectively, while:

$$
\begin{aligned}
& (E J)_{1}=(E J)_{2}=(E J)_{3}=(E J), \\
& (E A)_{1}=(E A)_{2}=(E A)_{3}=(E A), \\
& (\rho A)_{1}=(\rho A)_{2}=(\rho A)_{3}=(\rho A) .
\end{aligned}
$$

The column is connected at the free end with receiving head via infinitely rigid element with a length of $l_{0}$ and reduced concentrated mass $m$. This element is an integral part of the system and its taking into consideration is necessary having regard to the construction solution of loading head [12]. The flexural stiffness of abovementioned element is many times higher than the flexural stiffness of a slender system $[1,2]$. The positive pole $O$ is located at $\left(R-l_{0}\right)$ length from free end of column. 


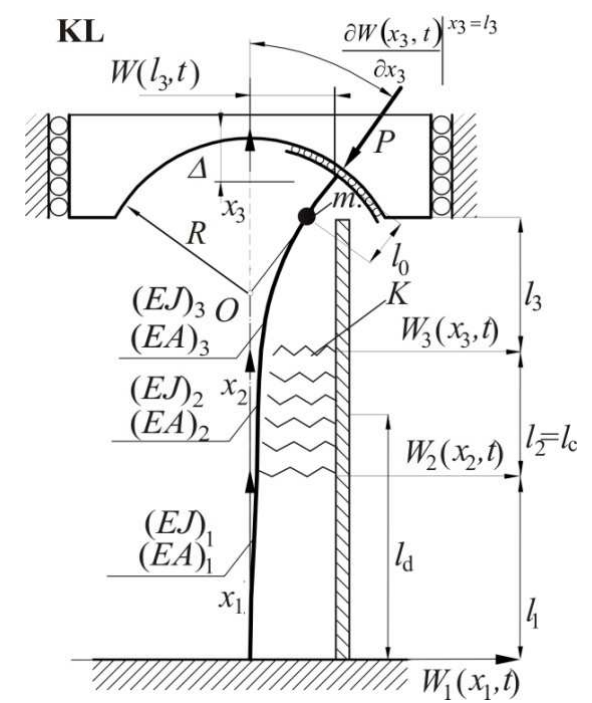

Fig. 1. The physical model of geometrically linear column (KL) locally resting on Winkler elastic foundation

Parameters describing location and length of Winkler foundation in relation to the total length may be written as:

$$
\begin{gathered}
l_{c}^{*}=\frac{l_{2}}{L}=\frac{l_{c}}{L}, \\
l_{d}^{*}=\frac{l_{1}+\frac{l_{2}}{2}}{L}=\frac{l_{d}}{L} .
\end{gathered}
$$

\section{Mechanical energy, equations of motion and boundary conditions}

Taking into account the physical model of considered column, components of kinetic and potential energies were determined according to the Bernoulli-Euler bending theory. Total kinetic energy $T$ is a sum of kinetic energies of particular rods of column and concentrated mass $m$ :

$$
T=\frac{1}{2} \sum_{i=1}^{3}(\rho A)_{i} \int_{0}^{l_{i}}\left(\frac{\partial W_{i}\left(x_{i}, t\right)}{\partial t}\right)^{2} d x_{i}+\frac{1}{2} m\left(\frac{\partial W_{3}\left(l_{3}, t\right)}{\partial t}\right)^{2} d x_{3} .
$$

The potential energy $V$ consists of following components:

- energy of bending elasticity $V_{1}$

$$
V_{1}=\frac{1}{2} \sum_{i=1}^{3}(E J)_{i} \int_{0}^{l_{i}}\left[\frac{\partial^{2} W_{i}\left(x_{i}, t\right)}{\partial x_{i}^{2}}\right]^{2} d x_{i}, \quad i=1,2,3,
$$


- potential energy $V_{2}$ resulting from external load $P$

$$
V_{2}=-\frac{1}{2} \sum_{i=1}^{3} P(E J)_{i} \int_{0}^{l_{i}}\left[\frac{\partial W_{i}\left(x_{i}, t\right)}{\partial x_{i}}\right]^{2} d x_{i}+\frac{1}{2} P\left(R-l_{0}\right)\left[\left.\frac{\partial W_{3}\left(x_{3}, t\right)}{\partial x_{3}}\right|_{x_{3}=l_{3}}\right]^{2}
$$

- potential energy of Winkler elastic foundation $V_{3}$

$$
V_{3}=\frac{1}{2} K \int_{0}^{l_{2}}\left(W_{2}\left(x_{2}, t\right)\right)^{2} d x_{2}
$$

The total potential energy is defined as:

$$
V=V_{1}+V_{2}+V_{3}
$$

The problems of stability and free vibrations of geometrically linear column were solved by using the Hamilton's principle [4]

$$
\delta \int_{t_{1}}^{t_{2}}(T-V) d t=0
$$

where $\delta$ - variation operator.

Taking into account equations (7) and (11), after mechanical energy variation computation, the following relations were obtained:

- equations of motion:

$$
\begin{gathered}
(E J)_{j} \frac{\partial^{4} W_{j}\left(x_{j}, t\right)}{\partial x_{j}^{4}}+P_{j} \frac{\partial^{2} W_{j}\left(x_{j}, t\right)}{\partial x_{j}^{2}}+(\rho A)_{j} \frac{\partial^{2} W_{j}\left(x_{j}, t\right)}{\partial x_{j}^{2}}=0, \quad j=1,3, \\
(E J)_{2} \frac{\partial^{4} W_{2}\left(x_{2}, t\right)}{\partial x_{2}^{4}}+P_{2} \frac{\partial^{2} W_{2}\left(x_{2}, t\right)}{\partial x_{2}^{2}}+(\rho A)_{2} \frac{\partial^{2} W_{2}\left(x_{2}, t\right)}{\partial x_{2}^{2}}+K W_{2}\left(x_{2}, t\right)=0
\end{gathered}
$$

- geometrical boundary conditions:

$$
\begin{array}{ll}
W_{1}(0, t)=0, & \left.\frac{\partial^{2} W_{1}\left(x_{1}, t\right)}{\partial x_{2}^{2}}\right|_{x_{1}=l_{1}}=\left.\frac{\partial^{2} W_{2}\left(x_{2}, t\right)}{\partial x_{2}{ }^{2}}\right|_{x_{2}=0}, \\
\left.\frac{\partial W_{1}\left(x_{1}, t\right)}{\partial x_{1}}\right|_{x_{1}=0}=0, & \left.\frac{\partial^{2} W_{2}\left(x_{2}, t\right)}{\partial x_{2}{ }^{2}}\right|_{x_{2}=l_{2}}=\left.\frac{\partial^{2} W_{3}\left(x_{3}, t\right)}{\partial x_{3}^{2}}\right|_{x_{3}=0}, \\
W_{1}\left(l_{1}, t\right)=W_{2}(0, t), & W_{2}\left(l_{3}, t\right)=\left.\left(R-l_{0}\right) \frac{\partial W_{3}\left(x_{3}, t\right)}{\partial x_{3}}\right|_{x_{3}=l_{3}},
\end{array}
$$


- natural boundary conditions:

$$
\begin{gathered}
\left.\frac{\partial^{2} W_{1}\left(x_{1}, t\right)}{\partial x_{2}{ }^{2}}\right|_{x_{1}=l_{1}}=\left.\frac{\partial^{2} W_{2}\left(x_{2}, t\right)}{\partial x_{2}{ }^{2}}\right|_{x_{2}=0}, \\
\left.\frac{\partial^{2} W_{2}\left(x_{2}, t\right)}{\partial x_{2}{ }^{2}}\right|_{x_{2}=l_{2}}=\left.\frac{\partial^{2} W_{3}\left(x_{3}, t\right)}{\partial x_{3}{ }^{2}}\right|_{x_{3}=0}, \\
\left.\frac{\partial^{3} W_{1}\left(x_{1}, t\right)}{\partial x_{1}{ }^{3}}\right|_{x_{1}=l_{1}}=\left.\frac{\partial^{3} W_{2}\left(x_{2}, t\right)}{\partial x^{3}}\right|_{x_{2}=0}, \\
\left.\frac{\partial^{3} W_{2}\left(x_{2}, t\right)}{\partial x_{2}{ }^{3}}\right|_{x_{2}=l_{2}}=\left.\frac{\partial^{3} W_{3}\left(x_{3}, t\right)}{\partial x_{3}{ }^{3}}\right|_{x_{3}=0} \\
\left.(E J)_{3} \frac{\partial^{3} W_{3}\left(x_{3}, t\right)}{\partial x_{3}{ }^{3}}\right|_{x_{3}=l_{3}}-\frac{1}{R-l_{0}}\left[\left.(E J)_{3} \frac{\partial^{2} W_{3}\left(x_{3}, t\right)}{\partial x_{3}{ }^{2}}\right|_{x_{3}=l_{3}}\right] \\
-m \frac{\partial^{2} W_{3}\left(l_{3}, t\right)}{\partial t^{2}}=0
\end{gathered}
$$

Condition $W_{3}\left(l_{3}, t\right)=\left.\left(R-l_{0}\right) \frac{\partial W_{3}\left(x_{3}, t\right)}{\partial x_{3}}\right|_{x_{3}=l_{3}}$ results from geometry of loading head.

\section{The solution of the boundary value problem}

After separation of variables in function $W_{i}\left(x_{i}, \mathrm{t}\right)$ in relation to time $t$ and spatial coordinates $x_{i}$, equations (13)-(14) may be formulated in form:

$$
W_{i}\left(x_{i}, t\right)=y_{i}\left(x_{i}\right) \cos \omega t,
$$

where $\omega$ - frequency of free vibrations of column.

Equation of motion may be written as:

$$
\begin{aligned}
& y_{j}^{I V}\left(\zeta_{j}\right)+k_{j}^{2} y_{j}^{I I}\left(\zeta_{j}\right)-\Omega_{j} y_{j}\left(\zeta_{j}\right)=0, j=1,3, \\
& y_{2}^{I V}\left(\zeta_{2}\right)+k_{2}^{2} y_{2}^{I I}\left(\zeta_{2}\right)-\Omega_{2} y_{2}\left(\zeta_{2}\right)+K_{2}\left(\zeta_{2}\right)=0,
\end{aligned}
$$

In relations (28)-(29) the following dimensionless parameters were taken into account: 


$$
\begin{aligned}
& \zeta_{i}=\frac{x_{i}}{l_{i}}, y_{i}\left(\zeta_{i}\right)=\frac{y_{i}\left(x_{i}\right)}{l_{i}}, K_{2}=\frac{K l_{2}^{4}}{E J}, k_{j}^{2}=\frac{P l_{j}^{2}}{E J}, \\
& \Omega^{*}=\frac{\rho A L^{4} \omega^{2}}{E J}, m^{*}=\frac{m}{\rho A L} .
\end{aligned}
$$

The general solution of differential equation (28) takes the following form:

$$
y_{j}\left(\xi_{j}\right)=A_{j} \cosh \left(\alpha_{j} \xi_{j}\right)+B_{j} \sinh \left(\alpha_{j} \xi_{j}\right)+C_{j} \cos \left(\beta_{j} \xi_{j}\right)+D_{j} \sin \left(\beta_{j} \xi_{j}\right) .
$$

Equation (29) has got three solutions that depend on mutual relations between external load $P$, natural frequency $\omega$ and stiffness of Winkler elastic foundation $K$ :

- $\omega \leq \sqrt{\frac{K_{2}(E J)_{2}}{(\rho A)_{2} L^{4}}-\frac{P^{2}}{4(E J)_{2}(\rho A)_{2}}}$

$$
y_{2}\left(\xi_{2}\right)=A_{2} e^{\alpha \xi_{2}} \sin \left(\beta \xi_{2}\right)+B_{2} e^{-\alpha \xi_{2}} \sin \left(\beta \xi_{2}\right)+C_{2} e^{\alpha \xi_{2}} \cos \left(\beta \xi_{2}\right)+D_{2} e^{-\alpha \xi_{2}} \cos \left(\beta \xi_{2}\right)
$$

where:

$$
\alpha=\frac{\sqrt{-k_{2}^{2}+2 \sqrt{K_{2}-\Omega_{2}^{2}}}}{2}, \quad \beta=\frac{\sqrt{k_{2}^{2}+2 \sqrt{K_{2}-\Omega_{2}^{2}}}}{2}
$$

- $\sqrt{\frac{K_{2}(E J)_{2}}{(\rho A)_{2} L^{4}}-\frac{P^{2}}{4(E J)_{2}(\rho A)_{2}}} \leq \omega \leq \sqrt{\frac{K_{2}(E J)_{2}}{(\rho A)_{2} L^{4}}}$

$$
y_{2}\left(\xi_{2}\right)=A_{2} \cos \left(\alpha \xi_{2}\right)+B_{2} \sin \left(\alpha \xi_{2}\right)+C_{2} \cos \left(\beta \xi_{2}\right)+D_{2} \sin \left(\beta \xi_{2}\right)
$$

where:

$$
\begin{gathered}
\alpha=\sqrt{\frac{k_{2}^{2}}{2}-\sqrt{\frac{k_{2}^{4}}{4}+\Omega_{2}^{2}-K_{2}}}, \quad \beta=\sqrt{\frac{k_{2}^{2}}{2}+\sqrt{\frac{k_{2}^{4}}{4}+\Omega_{2}^{2}-K_{2}}}, \\
-\omega \geq \sqrt{\frac{K_{2}(E J)_{2}}{(\rho A)_{2} L^{4}}} \\
y_{2}\left(\xi_{2}\right)=A_{2} \cosh \left(\alpha \xi_{2}\right)+B_{2} \sinh \left(\alpha \xi_{2}\right)+C_{2} \cos \left(\beta \xi_{2}\right)+D_{2} \sin \left(\beta \xi_{2}\right)
\end{gathered}
$$


where:

$$
\alpha=\sqrt{-\frac{k_{2}^{2}}{2}+\sqrt{\frac{k_{2}^{4}}{4}+\Omega_{2}^{2}-K_{2}}}, \quad \beta=\sqrt{\frac{k_{2}^{2}}{2}+\sqrt{\frac{k_{2}^{4}}{4}+\Omega_{2}^{2}-K_{2}}} .
$$

On the basis of solution of equation of motion (36), relation describing the dependency between external load $P$ and free transverse vibration frequency $\omega$ was obtained.

\section{Results of numerical computations}

Considering the solution of boundary problem (section 4), numerical research with reference to free vibrations of analysed system were conducted. The possible eigenvalues of column on external load parameter $\lambda^{*}$ (Eq. 49) - free vibration frequency parameter $\Omega^{*}$ (Eq. 34) plane were presented in Figures 2-4:

$$
\lambda^{*}=\frac{P L^{2}}{E J}
$$

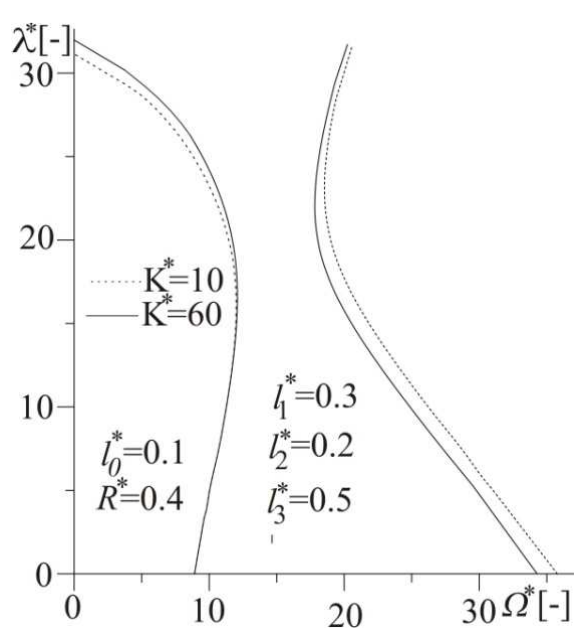

Fig. 2. The courses of the first two free vibration frequencies curves of KL column

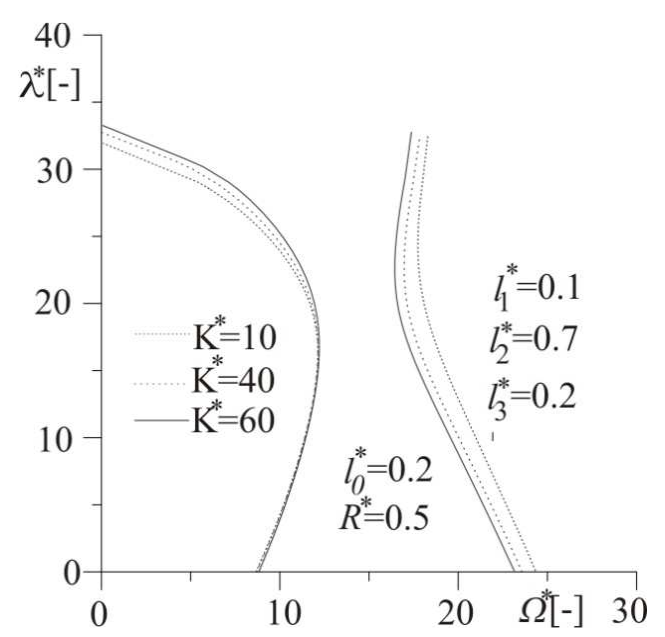

Fig. 3. The courses of the first two free vibration frequencies curves of KL column 


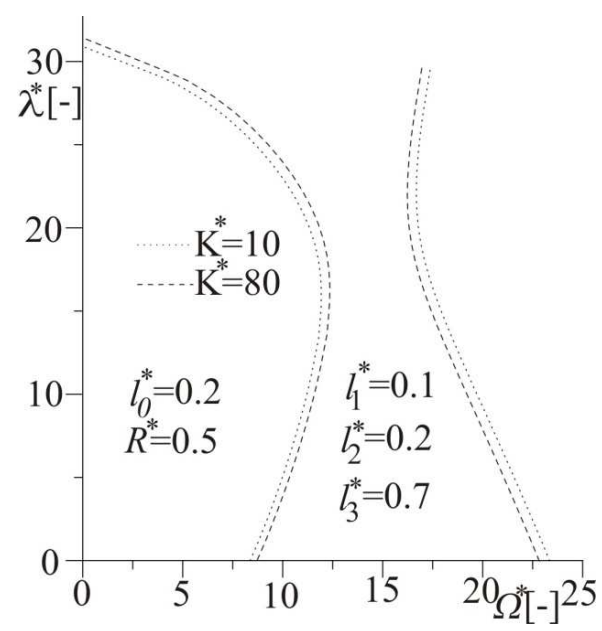

Fig. 4. The courses of the first two free vibration frequencies curves of KL column

The characteristic curves were determined for selected values of loading head parameters and with various values of parameters describing Winkler elastic foundation. In the front range the curve is positively sloped to the abscissa, then the slope is negative - free vibration frequency decreases and reaches zero under load corresponding to the critical load.

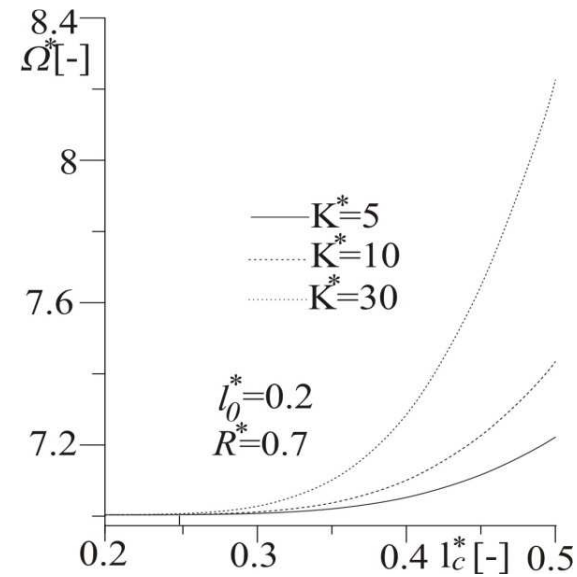

Fig. 5. A change of the first natural frequency parameter in relation to length of Winkler elastic base parameter $l_{c}^{*}$

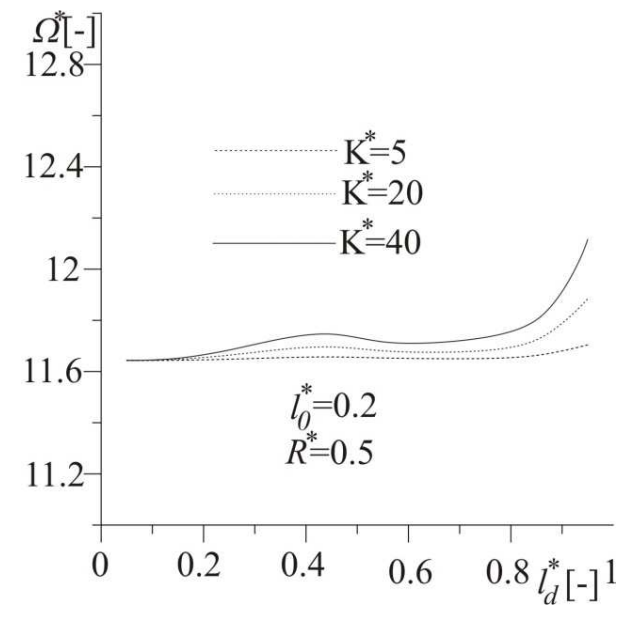

Fig. 6. A change of the first natural frequency parameter in relation to location of Winkler foundation parameter $l_{d}{ }^{*}$

The influence of length of Winkler elastic foundation $l_{c}^{*}$ and its location $l_{d}^{*}$ (Eqs. (2)-(4)) on the values of first free transverse vibration frequency of KLW system was presented in Figures 5 and 6 . The numerical computations were carried out for selected values of loading head parameters. 


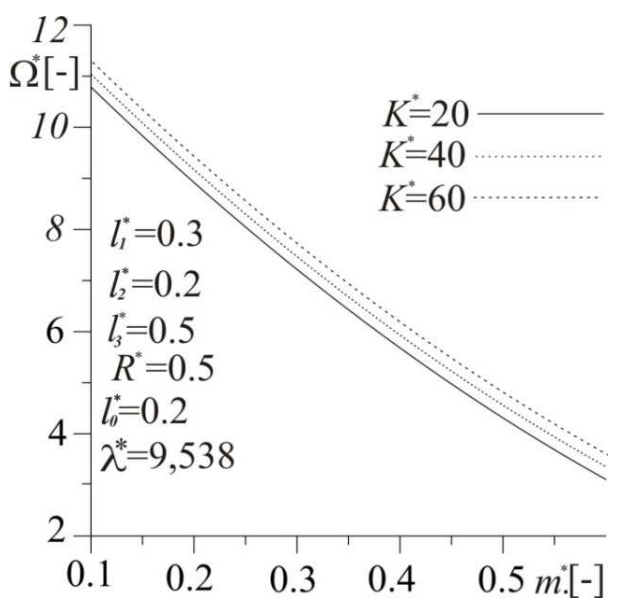

Fig. 7. The influence of the concentrated mass $m^{*}$ on natural frequency parameter

The scope of change in the first natural frequency corresponding to the external load parameter equals $\lambda^{*}=9.538$ was presented in Figure 7 . The calculations were performed for selected values of parameters of loading head and parameters characterizing elastic foundation. It was proven that the first natural frequency decreases with the rising value of concentrated mass.

\section{Conclusions}

Research into free vibrations of column under follower force directed towards positive pole taking into consideration Winkler elastic foundation was the aim of this paper. On the basis of courses of first two free vibration frequencies curves it was found that considered system is classified as divergence pseudo-flutter type. Parameters describing length and location of elastic foundations have influence on the value of free vibration frequency. Consideration of Winkler elastic base in physical model of column increases the value of vibration frequency. The value of critical load increases with the stiffness of elastic foundation.

\section{Acknowledgments}

The study has been carried out within the framework of project BS/PB-1-1013020/11/P realized at Czestochowa University of Technology.

\section{References}

[1] Leipholz H.H.E., On conservative elastic systems of the first and second kind, IngenieurArchiv 1974, 43, 255-271. 
[2] Tomski L, Szmidla J., Drgania swobodne i stateczność kolumn poddanych działaniu swoistemu - sztywne węzły konstrukcyjne układu wymuszającego i przyjmującego obciążenie, rozdział III, [w:] Drgania i stateczność układów smukłych, praca zbiorowa wykonana pod kierownictwem naukowym i redakcją L. Tomskiego, Wydawnictwo Naukowo-Techniczne, Fundacja Książka Naukowo-Techniczna, Warszawa 2004.

[3] Beck M., Die Knicklast des einseitig eingespannten tangential gedruckten Stabes, ZAMP 1953, 4, 225-228, 476-477.

[4] Tomski L., Szmidla J., Drgania swobodne i stateczność wspornikowych kolumn geometrycznie nieliniowych poddanych obciążeniu swoistemu, rozdział VI, [w:] Drgania swobodne i stateczność obiektów smukłych jako układów liniowych lub nieliniowych, praca zbiorowa wykonana pod kierownictwem naukowym i redakcją L. Tomskiego, Wydawnictwo Naukowo-Techniczne, Fundacja Książka Naukowo-Techniczna, Warszawa 2007.

[5] Bogacz R., Imiełowski Sz., Tomski L., Stability and vibration of column structures subjected to generalized concentrated load, Theoretical and experimental study, Dynamics of Continua International Symposium, Physikzentrum Bad Honnef, 9-13 September 1996, 45-54.

[6] Uzny S., Drgania swobodne i stateczność kolumny poddanej obciążeniu czynnemu i biernemu siłą śledzącą skierowaną do bieguna dodatniego, rozdział V, [w:] Drgania swobodne i stateczność układów smukłych poddanych obciążeniu konserwatywnemu i niekonserwatywnemu, praca zbiorowa wykonana pod kierownictwem naukowym i redakcją L. Tomskiego, Wydawnictwo Naukowe PWN, Warszawa 2012.

[7] Szmidla J., Drgania i stateczność kolumn spoczywających na podłożu typu Winklera realizujące wybrane przypadki obciążenia konserwatywnego, Zeszyty Naukowe Politechniki Rzeszowskiej, seria Mechanika 2008, 258, 74, 321-332.

[8] Oniszczuk Z., Drgania belki na inercyjnym podłożu sprężystym, Mechanika Teoretyczna i Stosowana 1991, 2, 29.

[9] Chonas S., Dynamical behaviours of elastically concerted double-beam system, subjected to an impulsive load, Bulletin of the JSME 1976, 19, 132.

[10] Pozorska J., Pozorski Z., The influence of the core orthotropy on the wrinkling of sandwich panels, Journal of Applied Mathematics and Computational Mechanics 2015, 4(14), 133-138.

[11] Studziński R., Pozorski Z., Błaszczuk J., Optimal support system of sandwich panels, Journal of Engineering Mechanics 2015, 04014133, 141, 3, 1-8.

[12] Tomski L., Szmidla J., Opis techniczny struktur obciążających kolumny, rozdział II, [w:] Drgania swobodne i stateczność obiektów smukłych jako układów liniowych lub nieliniowych, praca zbiorowa wykonana pod kierownictwem naukowym i redakcją L. Tomskiego, Wydawnictwo Naukowo-Techniczne, Fundacja Książka Naukowo-Techniczna, Warszawa 2007. 